\title{
Recognition, symbolic capital and reputation in the seventeenth century: Thomas Hobbes and the origins of critical public relations historiography
}

\author{
Jordi Xifra ${ }^{\mathrm{a} *}$ \\ a Department of Communication, Pompeu Fabra University, Barcelona, Spain \\ * Tel.: + 349354214 84; e-mail: jordi.xifra@upf.edu
}

\begin{abstract}
The intellectual history of public relations has not paid attention to British political philosopher Thomas Hobbes. This article aims to close this gap. Following the so-called philosophy of prestige (Carnevali, 2012), the article applies Hobbes' doctrine of natural law and human passions to public relations historiography. Indeed, considering recognition and reputation to be critical elements for human beings in a conflictual society in which gaining power was the main goal, Hobbes anticipated critical public relations thinking. In the Hobbesian system, because recognition is a social capital, reputation management becomes the most appropriate relational strategy to negotiate and gain power. Accordingly, uncertainty characterizes reputation and dealing with it fits into risk management. Although Hobbes never used the concepts of public relations or reputational risk, he was the first thinker to approach social relations from a conflictual perspective and view reputation as a risk deriving from it. Thus, through his approach, Hobbes opened up a new perspective, differing from those of other renowned Renaissance thinkers like Machiavelli or even some of his contemporaries, like Gracián, who also dealt with the idea of reputation.
\end{abstract}

Keywords: Thomas Hobbes; Symbolic capital; Reputation; Recognition; Public Relations Historiography; Intellectual history

\section{Introduction}

The history of thought is rich in examples — for instance, alienation - in which the intuition and elaboration of a problem preceded the invention of the concept itself and of any specific terminology for it (Carnevali, 2013). Even if it cannot be considered a philosophical or sociological conceptual category, this appears to be true of public relations, at least for some public relations historians. Indeed, as Fitch and L'Etang (2017) point out, for "some authors public information and propaganda are part of the story and may encompass centuries; for others, PR history is limited to the emergence of a commercial occupation and 'professional' bodies" (p. 131). Other scholars, like Moore (2014), prefer to use the expression "managed public communication" (p. 3).

In contrast with the above, the idea of reputation - considered as the idea, the consideration or, better still, the esteem that partners of an individual have of his/her value within the interaction, i.e., as a form of social recognition (Honneth, 1996) - is one of those notions in which the intuition and foundation of a problem preceded the creation of the concept and of a precise terminology for it. Although the 
historiographical tradition considers philosophical knowledge regarding this problem to have appeared with German idealism (Carnevali, 2013) and coincided in particular with the elaboration of the technical concept of Anerkennung by Fichte and Hegel (Williams, 1992; Honneth, 1996), it is difficult to believe that recognition - the eternal trait of the human condition, at least if one accepts a definition of man as a social beingrepresents an original discovery of nineteenth-century thought. As Carnevali (2013) puts it, "this idea is only a simplification deriving from a too restricted use of the word recognition” (p. 49).

It would, however, be problematic — at least from the historiographical point of viewto consider Plato and Saint Augustine's theories on love, or Aristotle's approach to friendship, for instance, as ancient philosophies of recognition, even if they are antecedents of the current idea of recognition. Thus, the purpose of this essay is to provide a theoretical and historical context that elucidates (1) whether there is a specifically modern approach to the subject of reputation and recognition, (2) whether this approach appeared before Hegel, and (3) whether this perspective can be considered a turning point in the influence the history of ideas had in shaping a historiography of public relations. Following Carnevali (2013), we can assert that the work of Thomas Hobbes allows us to answer both questions efficiently thanks to two aspects that can be considered fully relevant today.

Hobbes first developed a new metaphysical paradigm of subjectivity, centered on the law of individual self-affirmation. This new configuration of the ego finds an exemplary expression in his theory of natural law (Hobbes, 1969), focused on the relationship between power and freedom, and rightly considered as a point of rupture between the anthropology of the ancients and that of the moderns. In parallel with this philosophical turn, modernity was accompanied by important historical and social transformations: the disentangling of recognition in social contexts was turning identity into a stage for conflictual negotiation. Social value was no longer a direct result of individuals' economic or social status, but necessarily derived from the self - a self defined as a unique, private, personal and non-institutional entity. In a traditional society, recognition is not perceived as a problem because it is spontaneously included in the collective categories of social identity (Strauss, 1936). On the other hand, when individuals begin to free themselves from the chains of the social order, their identity is no longer automatically defined by the roles assigned to it by tradition: it must be constructed in a more autonomous and unpredictable form, through a dialogical and conflicting relationship with others (Carnevali, 2013). Thus, according to Taylor (1989), what was born with modernity was not the need for recognition, but the struggle for recognition and the possibility of failing in this struggle; and, consequently, the uncertain nature of the outcome of that struggle, i.e., reputation. Closely related to the former aspect, the latter refers to the fact that conflict becomes the privileged paradigm of the interpretation of social relations. Hobbes' most popular expressions and formulas -homo homini lupus (a man is a wolf to another man), bellum omnium contra omnes (the war of all against all)- among other features confirm that he marked a turning point in the philosophy of conflict. Indeed, because of the tumultuous period in which Hobbes lived and the influence of Thucydides' History of the Peloponnesian War - which was his first printed work, published in 1629- (Sowerby, 1998), Hobbesian doctrine is always immediately associated with the endemic nature of war (Ryan, 2015). 
The combination of these two elements is present in all modern theories of recognition (e.g. Butler, 1990; Honneth, 1996; Ricoeur, 2005; Carnevali, 2012). We are therefore faced with a new difficulty - that of elucidating which theoretical models on conflict will be most useful for our study. Conflict is not the same for Hobbes as for Hegel. Even within the same school of thought, we find different approaches to this philosophical and sociological phenomenon. Now, this article is not a philosophical essay, but a work that attempts to legitimize the origins of an intellectual history of critical public relations. Accordingly, our approach is one of the more widely accepted, the main feature of which is to reduce recognition to a strategic model of action and communication for maximizing power and magnifying social status (Bourdieu, 1990; Honneth, 1996, 2002). This model has its roots in the political philosophy of Thomas Hobbes, and particularly in his books Elements of Law, Natural and Politic (1640) and Leviathan, or The Matter, Forme and Power of a Common Wealth Ecclesiasticall and Civil (1651). As Piirimäe (2006) demonstrated, Hobbes' theory regarding the need for an absolute sovereign, put forward in Leviathan, rests upon the argument that anarchy is a condition of violent conflict. To Hobbes, it is therefore crucial to demonstrate that, despite being predominantly rational creatures, humankind is unable to arrange and keep cooperative agreements without enforcement by the State.

On the other hand, Hobbes (1969) analyzes human passions in-depth, and establishes one of his fundamental theoretical assumptions: the existence of an essential link between the question of recognition and that of power (Slomp, 2014). We agree with Carnevali (2013) when she argues that the originality of this approach can be found at the level of terminology itself, in the complementary nature of the two terms at the center of Hobbesian anthropology: power and glory, or, in more accurate and current terms, hegemony and reputation.

\section{Hobbes on reputation as social and symbolic capital}

Reputation was one of Hobbes' main concerns, and he dealt with it via other philosophical concepts such as glory, honor or recognition, as versions of reputation. In fact, he wrote a text entitled Considerations upon the Reputation, Loyalty, Manners, \& Religion of Thomas Hobbes of Malmsbury (1680), in which we find his concern regarding social recognition. However, this text is an autobiographical work and not a crucial source on Hobbes' approach to reputation. The most important is Elements of Law, in which Hobbes breaks from the classical anthropology that had tied the individual quest for pleasure and happiness to an objective and hierarchical vision of good. In contrast, the British thinker studied human nature from a naturalistic and mechanistic perspective, focusing on the metaphysical principle that individuals share with all living beings: endeavor (conatus), that is, the effort by which the individual seeks to preserve his own life and gradually increase his power (Hobbes, 1969). In other words, the theory of natural law frees human beings from this inflexible network of objective laws by legitimizing the right to competitive self-assertion and by paving the way for an anthropology of the will to power (Lazzari, 1990).

Hobbes believed in two central types of passion that are differentiated by the form of "good" they aim for: utility (utilitas) and glory (gloria). These can be referred to as material passions and symbolic passions (Carnevali, 2013). Physical passions seek physical pleasure by turning to material objects, such as food, drinks, or sexual 
relationships. Symbolic passions are aimed at symbolic objects the soul enjoys in a spiritual way, not via the senses, but through the ability of imagination. These two categories of passions are separated by a notable difference - the different quality of the pleasure sought and the different relationship this good maintains with physical needs. However, a fundamental analogy unites them: both utility and glory arise from the impulse, the effort, which pushes the ego to accumulate an infinite power by perpetually transcending its limits and repelling all the obstacles it finds on its way (Slomp, 2014). Whereas at the material level this impulse translates into an unlimited desire for sensual enjoyment and physical possession, which necessarily collides with the identical desire of other subjects, at the spiritual level it expresses itself in as unlimited desire for power, and more precisely a superiority over the power of others, for which Elements of Law provides this lapidary definition:

"GLORY, or internal gloriation or triumph of the mind, is that passion which proceedeth from the imagination or conception of our own power, above the power of him that contendeth with us" (Hobbes, 1969, IX, 1).

The word glory evokes the classical tradition, which Hobbes liked and frequented assiduously. Its etymology comes from the Greek kléos whose phonetic root, as linguists and philologists have often noticed, refers to the fame that circulates in the public space, which "resonates" and is thus socially recognized and celebrated (Carnevali, 2013). This leads us to another essential element of the Hobbesian model. Sensed by the subject as an inner feeling of satisfaction and power, glory is attested by others in the form of honor. To honor someone, as Hobbes specifies, is to establish the value of an individual in a comparative way, to evaluate the superiority of his power in relation to that of his competitors (Bagby, 2009):

"...the acknowledgment of power is called HONOUR ; and to honour a man (inwardly in the mind) is to conceive or acknowledge, that that man hath the odds or excess of power above him that contendeth or compareth himself (Hobbes, 1969, VIII, 5).

In Hobbes' model, honor is something between a passion and a manner but is not exactly either. It cannot be an emotion because honor is related to the social structure, which is artificial, but then again because honor is a sign that other people value us, it is something that belongs to human nature (Lemetti, 2012). In Leviathan, he wrote:

"The manifestation of the Value we set on one another, is that which is commonly called Honouring, and Dishonouring. To Value a man at a high rate, is to Honour him ; at a low rate, is to Dishonour him. But high, and low, in this case, is to be understood by comparison to the rate that each man setteth on himself" (Hobbes, 1996, I, X).

The honor felt in the inner judgment in the form of mental judgment must also be expressed externally, on the public stage, in the form of signs of honor. These are gestures, words, symbols, titles, ceremonies, gifts, to which the signification of a testimony of esteem, of a positive evaluation is attributed in a consensual way:

"The signs of honour are those by which we perceive that one man acknowledgeth the power and worth of another. Such as these : - To praise ; to magnify ; to bless, or call happy ; to pray or supplicate to ; to thank ; to offer unto or present ; to obey ; to hearken 
to with attention ; to speak to with consideration ; to approach unto in decent manner ; to keep distance from ; to give the way to, and the like" (Hobbes, 1969, VIII, 6).

As Carnevali (2013) points out, this semiotic or symbolic moment corresponds with the dimension of the recognition which one could define as "aesthetic" in the sense of aisthesis: "the honorary sign is a sensitive phenomenon which expresses a spiritual content and is susceptible of being perceived" (p. 54). Honor is indeed an immaterial and mental entity - it is "secret and internal in the heart" (Hobbes, 1996, XLV, 12)-, but it also has phenomenal features - visible, audible, tangible - that correspond to its public manifestation and that are of the most social importance, insofar as they bring about the objective existence of personal value. These signs of honor are precisely the ones that represent the goods coveted by the consciousness in search of glory. The symbolic passions try to satisfy the insatiable needs of the conatus by accumulating praise, honorary titles, reverences, smiles, signs of preference and distinction. This immaterial food is to the mind what bread and water are to the body: the awareness of a lack of esteem feeds on the symbols of its own value that are reflected by the awareness-mirrors of its social partners (Carnevali, 2013). From this standpoint, Hobbes sets out a philosophy of social aesthetics and frames it under the theatrical umbrella of public recognition; a philosophy developed later by different thinkers, of whom Georg Simmel was the leader (Frisby \& Featherstone, 1997).

\section{Reputation as uncertainty and risk}

Thus, another key feature of the modernity of Hobbes' thinking emerges: glory and honor are two complementary concepts that express the subjective and objective moment of recognition, respectively. Furthermore, in the Hobbesian model, honor becomes a simple positional good, a distinction without content. What the subject seeks in honor is not the admiration of his virtue, but the confirmation of his superior status, the external attestation of that purely social excellence which, in more modern terms, we call reputation (Piirimäe, 2006). From this perspective, Hobbes preceded Marx.

Hobbes indeed turned the need for recognition into one of the key issues of modern political philosophy, from a psychological as well as a social point of view. From the psychological standpoint, the need for recognition is not one of many elements of human nature, but the true keystone of the subjective psychological structure. Profound causes of human desire rise at its source (at least in Elements, where all secondary passions are deduced from glory, the primary and dominant passion). That said, however, it should be stressed that in relation to the broad spectrum of affective phenomena that may be associated with the issue of recognition, Hobbes makes a very selective choice, focusing exclusively on one aspect of the need for recognition, that of competition for power and superiority of status (Slomp, 2014). From the sociological standpoint, the need for recognition is a relational passion that involves a relationship of dependence and comparison with others and is superimposed on the desire for power displayed by the conatus, the need for recognition becomes the keystone of the social order as well (Zarka, 2016).

In the Hobbesian model, 
“... the equilibrium of intersubjective connexions is determined by the tension between two opposing impulses, also produced by the desire for glory: to the affirmative impulse exerted at the expense of others necessarily opposes the need of others, indispensable to guarantee individual consciousness the attestation or the external proof of its value. At the origin of the social problem of modernity, according to Hobbes, there is thus an inescapable contrast between desire for power and dependence, aggressiveness and vulnerability" (Carnevali, 2013, p. 55).

This ambivalence is also found in one of the most innovative intuitions in Hobbes' philosophy: the symbolic dynamics of social conflict. The hostility that opposes individuals is not determined exclusively by material causes such as the scarcity of resources driving individuals to conflict. The endemic condition of war also arises from an insatiable desire for elective honorable goods. Thus, a serious impact of reputation lies in its role in conflicts. Indeed:

"So that in the nature of man, we find three principal causes of quarrel. First, competition; secondly, diffidence; thirdly, glory. The first maketh men invade for gain; the second for safety; and the third for reputation" (Hobbes, 1996, XIII, 88).

The third is manifested in "trifles, as a word, a smile, a different opinion, and any other sign of undervalue, either direct in their Persons, or by reflection in their Kindred, their Friends, their Nation, their Profession, or their Name" (Hobbes, 1996, XIII, 61-62). The struggle for reputation erodes society, then, and Hobbes links this mechanism mainly to religious and political enthusiasts, as well as intellectuals (Lemetti, 2012, p. 281). Moreover, glory evidences the specific difference of the human being, who is distinguished from the animal by the pursuit of entirely symbolic stakes: "there is a certain dispute between men of honor and dignity which is not found among beasts" (Hobbes, 1998, II.V.5), and it is the third of these causes that renders the conflict insoluble. Certainly, for Hobbes the individual is not an autonomous, closed, independent entity. He suffers from the company of others, but he needs this company to know the value of his self and to enjoy the pleasure of domination and excellence. Far from aspiring to inner autarky, there is a curious paradox of unsociable sociability: he needs others in order to despise them (Carnevali, 2013).

In this anthropological context, glory plays an archetypical role, insofar as it presupposes an intersubjective definition of what the individual holds most precious, which is the idea of his own value (Slomp, 2014). The image and appreciation Hobbesian consciousness has of itself does not arise spontaneously and immediately from inner feeling; on the contrary, this image must be mediated by other consciences, for at least two reasons.

First of all, because glory, like all symbolic attestations, depends on the inclinations of others - it must be "recognized", conferred by another subject. The symbolic good of honor - unlike material goods (e.g. the quantity of food or drink necessary to satisfy one's hunger or thirst) - cannot be obtained and consumed solely on the basis of individual desire. It depends on the attitude and behavior of others. Thus, honor is always granted, and anchored, in a constant state of uncertainty. Managing honor and reputation is, in the Hobbesian system of things, the management of uncertainty. In management today, understanding organizational uncertainty is imperative to the success of an organization; and contingency planning is essential in crisis, risk, and 
issues management (Heath \& O'Hair, 209). From this standpoint, and according to Hobbes' model, like today's reputation honor is a risk (Xifra \& Ordeix, 2009).

The second reason stems from the metaphysical and anthropological presuppositions propounded by Hobbes. In particular, the idea that self-knowledge conveyed by glory is always relative and conflictual: there is no external and absolute normative order in relation to which the individual can measure his value. Individual assessment is always positional: social value consists of being qualitatively "inferior" or "superior" in comparison with someone else.

Consequently, as Lemetti (2012) argues, Hobbes' analysis of reputation is psychological. In The Elements of Law (I, 8, 5), he considers "general reputation amongst those of the other sex" as honorable, though it remains somewhat unclear what the exact meaning of "general" is here. Other interesting remarks are that "SHAME, or the passion that discovereth itself in BLUSHING; and consisteth in the apprehension of some thing dishonourable; and in young men, is a sign of the love of good reputation" and that "The contempt of good reputation is called IMPUDENCE" (Hobbes, 1996, VI, 27).

Reputation in itself is not, however, a passion, but an instrumental power. It is this aspect of reputation that Hobbes analyzes in Leviathan, writing, for instance, that "Reputation of power, is power; because it draweth with it the adherence of those that need protection" and "what quality soever maketh a man beloved, or feared of many; or the reputation of such quality, is power" (Hobbes, 1996, X, 41). Losing reputation is also an important topic, which Hobbes discusses in the context of religion. According to Hobbes, the Roman Catholic clergy lost its reputation completely on the grounds "both of Ignorance, and of Fraudulent intention; and enclined people to revolt from them, either against the will of their own Princes, as in France and Holland; or with their will, as in England" (Hobbes, 1996, XII, 59).

\section{The legacy of Hobbes' model in (public relations) critical thinking}

In the Hobbesian model, then, the question of reputation plays an essentially political role in two complementary perspectives: not only is it used to explain the symbolic origins of conflict, but it also serves to justify the urgency of institutional regulation by the State:

"It is necessary that there be Lawes of Honour, and a publique rate of the worth of such men as have deserved, or are able to deserve well of the Common-wealth ; and that there be force in the hands of some or other, to put those Lawes in execution. [...] To the Soveraign therefore it belongeth also to give titles of Honour ; and to appoint what Order of place, and dignity, each man shall hold; and what signes of respect, in public or private meetings, they shall give to one another" (Hobbes, 1996, XVIII, 10).

As part of the honorary hierarchy legally imposed by the sovereign, honor becomes the public recognition of the best servants of the commonwealth, and no longer the floating value which, in the state of nature of individuals, obeys laws similar to those of the market. Thus, Hobbes develops a normative solution to the issue of glory. Now, as a political thinker he did not aim for an internal transformation of the individual, i.e., he 
did not seek this solution at the ethical level, but at the State level. Carnevali (2013) compares this normative solution with contemporary theories advocating a democratic distribution of recognition, mediated by law and institutions, and in particular with Honneth's $(1996,2002)$ theory of public esteem.

But the fertility of the Hobbesian model also manifests itself in its more explanatory and descriptive dimension, giving rise to the philosophical, sociological and anthropological tradition that considers recognition in the same light as honor and sees in the struggle for reputation an unavoidable dimension of social reality: this line, which passes through Rousseau, Kojève, Veblen, Mauss and Elias, spans from Mandeville to the recent work of economists attempting to reconstruct the theory of value (Orléan, 2011). Nonetheless, it is in the work of Bourdieu $(1984,1986,1990,1991)$ that we discover the most systematic and coherent Hobbesian legacy.

The sociological and philosophical presuppositions of Bourdieu's theory are essentially the same as those espoused by Hobbes. In an anthropology based on the desire for power (although independent in the sociologist of an explicit metaphysical foundation), the distinction between the two different forms of good that comprise the subject of the strategic quest for power - the material goods of economic resources and the intangible goods of symbolic resources - corresponds to the centrality of honor and an endemic conception of conflict. In these two spheres, the individual is guided by the same vital interest and the same tendency to assert oneself. Bourdieu's (1984) theory of distinction is based on one basic principle: the primary objective of social agents is to maximize their social power and the accumulation of symbolic capital is a fundamental element in this strategy. This notion of symbolic capital is revealing, insofar as it designates the amount of honorary recognition that an individual or a group can capitalize by artificially manipulating the cultural system. Thus, the issue of reputation and recognition is absorbed within a strategic and utilitarian conception. As Carnevali (2013) states: "This process marks an important turning point in the history of materialism... it opens up a new field, infinitely rich and fascinating, for the phenomenology and the hermeneutics of the symbolic conflicts of power" (p. 63). Furthermore, Bourdieu (1990) presents the "economy of practice" as a theoretical model that embraces every form of action and every form of good - material or symbolic under the sign of one and the same paradigm of action. Put differently, the experience of recognition is merely the pursuit of power by other means (Honneth, 1995).

As public relations scholars have shown (e.g. Ilhen, 2005, 2007; Edwards, 2006; Taylor, 2011; Sommerfeldt, 2013; Dodd et al., 2015), social and symbolic capital are two concepts that fit in well "with much public relations thinking that emphasizes how relationship building has both short and long-term effects for an organization" (Ihlen, 205 , p. 494). From this viewpoint, Edwards (2006) proposed a research agenda in which:

"...the symbolic capital that defines the field and its structures will be revealed; the nature of public relations as a form of symbolic production generating symbolic power will be clarified; and the limits of the symbolic power of public relations will emerge more clearly" (p. 231).

In addition, the utilitarian perspective of conflict in Hobbes' model has served for some scholars to offer a game theory approach to it (Pizzorno, 1991; Piirimäe, 2006). This 
approach is similar to that put forward by Murphy (1991) in offering a critical view of the 'Grunigian' paradigm (Moloney, 2002). Indeed, as game theory avoids the polarization of symmetric and asymmetric public relations, it offered a more realistic perspective (Murphy, 1991). This primal critical approach is an extension of the Hobbesian angle on reputation management. Furthermore, as we have pointed out, the conflictual nature of the quest for and management of reputations turns it into a risk: the risk of losing power.

Hobbes thus belongs to what has been called the history of ideas in the field of public relations (Moore, 2014). Nonetheless, he is not just another thinker, as his ideas represent the turning point between a classical idea of reputation and a (pre)critical one. As mentioned above, the novelty of Hobbes' thinking in comparison with past and coetaneous thinkers such as Castiglione, Machiavelli or Gracián, is the consideration that the identity of human beings must be constructed in a more autonomous and unpredictable form, through a dialogical and conflicting relationship with others. In other words, until the seventeenth century, the intellectual history of public relations focused on aspects that affected impressions rather than reputation. García (2017), in his analysis of Gracián, emphasizes that as a Baroque author his concept of prudence was based on conceiving life as the art of representation, in which the facade, as with any Baroque church, was the most important element. To this end he cites the following two Gracián (1992) aphorisms: "The great person should prefer celebrated occupations that all can see and share" (aphorism 67; p. 38), and "Things pass for what they seem, not for what they are. Only rarely do people look into them, and many are satisfied with appearances" (aphorism 99; p. 55).

These aphorisms confirm the idea that until the arrival of Hobbes, thinkers worried about the reputation, honor and recognition of the human being, in short, about the public image, formulating a noncontroversial view of reputation management as good reputation was understood as a value of the elites derived from a chivalrous vision typical of the late Middle Ages (Thomas, 1965). For thinkers like Machiavelli, Castiglione or Gracián, rulers or courtiers managed reputation in a context free from competition; they therefore managed their impressions, rather than their reputations. Certainly, prior to Hobbes there was no sociological or anthropological basis for speaking about the idea of reputational risk as we know it today. From this standpoint, while thinkers such as Gracián —along with others, like Plato, in which, for instance, we can find the origins of Grunig's models of public relations, each one represented by one of the four protagonists of the Gorgias dialogue: Gorgias, Polus, Calicles, and Socrates - may be regarded as clear inspirers of the late twentieth century dominant public relations paradigm of excellence, based on the two-way symmetry of the effects of the communication process, Hobbes' emergence offers a new dimension closer to what we today know as the critical approach to public relations, in which reputation is used to create and enact power and, consequently, hegemony.

\section{Hobbes and the intellectual history of public relations: a conceptual proposal and further developments}

Recently, public relations scholars have published books and articles on how the socalled history of ideas may prove a useful field for improving the current practice of public relations (Ihlen et al., 2009; Moore, 2012, 2014; García, 2010, 2015, 2017; 
Marsh, 2013). Some of these studies have focused more on the sociological dimension of the studied theories and thinkers (for instance, Ihlen et al., 2009), while the majority can be included within the history of ideas. Their approach is practically the same: to analyze how the work of world-renowned intellectual thinkers set a precedent for public relations as an expression or profession, based on the principle that even if these thinkers were ignorant of public relations, public relations cannot ignore them. From this standpoint, García (2010) has argued that it should be taken into account how the history of ideas has influenced the perspectives adopted by public relations practice. In addition, he has also called for more attention to be paid to other aspects of the history of ideas to better understand the spirit of the profession, such as the historical impact of political ideas on the practice of public relations, especially from an ethical dimension.

Hobbes' contribution forms part of this historiographical tradition of public relations, but contributes a new level of thought, that of his critical approach. As has been mentioned, Hobbes was not just another thinker - he was the first to offer a critical view of recognition and reputation. In contrast with some of his contemporaries - e.g. Spinoza (García, 2015) or Gracián (García, 2017) - it is not a question of viewing him as someone who recovered some of Machiavelli's postulates, leaving aside the ethical dimension. Hobbes was a philosopher who denounced the warlike conflicts that afflicted the England of his time and attempted to analyze them from an anthropological and political perspective (Sowerby, 1998). It is an analysis that has remained relevant today and whose foundations have served to build a critical theory of public relations based, among other aspects, on the concepts of power and hegemony (Roper, 2005; Coombs \& Holladay, 2012.; Heath \& Xifra, 2014).

For this reason, we believe that by incorporating Hobbes' work into the history of public relations we can differentiate between the history of ideas and intellectual history. Although Gordon (2012) warns us that the difference between these two concepts can be confusing since they are often interchanged, the history of ideas is a "discipline which looks at large-scale concepts as they appear and transform over the course of history" (p. 1-2). Therefore, a historian of ideas will tend to organize the historical narrative around one major idea, following its development or metamorphosis as it manifests itself in different contexts and times. We do not believe that public relations can be considered a "large-scale concept", and the same is true of critical public relations. In contrast, ideas and concepts such as power, hegemony and, of course, public recognition or reputation, are unavoidable when constructing a prehistory, protohistory and history of public relations. From this perspective, while other thinkers are concerned with important aspects and ideas tangentially linked to the ontology of public relations, such as ethics - i.e. Spinoza (Garcia, 2015) - or activism -i.e. Gandhi (Moore, 2014), Hobbes - like Plato, Al-Farabi, Machiavelli (Moore, 2012) or Gracián (García, 2017) — is one of the most outstanding intellectuals to have examined the idea of reputation, public image and recognition - even publishing a book on his own reputation (Considerations upon the Reputation, Loyalty, Manners, and Religion of Thomas Hobbes, 1680). Consequently, Hobbes can be included within the intellectual history of public relations as a pioneer who offered a different perspective very fruitful for today's critical thinkers.

From this analysis of Hobbes' work, we can propose a distinction between what would be a history of ideas for public relations - which has to analyze how key concepts for the theoretical and professional development of the field have been approached by 
different thinkers (philosophers, sociologists, anthropologists, political scientists) — and an intellectual history of public relations, which should include the historical and historiographical study of how key concepts for the ontology of public relations have been treated by these same thinkers throughout history, even before the institutionalization of public relations as a profession.

Intellectual history offers an epistemological opportunity to introduce public relations to other disciplines. As Gordon (2012) argues:

"Intellectual history does not necessarily require that concepts be studied within a larger, non-conceptual frame...Indeed, intellectual historians, as opposed to historians of ideas and philosophers, tend to be more relaxed about crossing the boundary between philosophical texts and non-philosophical contexts... [they regard] the distinction between 'philosophy' and 'non-philosophy' as something that is itself historically conditioned rather than eternally fixed" (pp. 2-3).

Consequently, the idea of applying the current concept of public relations and reputation management to the past is a form of "controlled anachronism" (Landi, 2012, p.25) intended to adapt their theory to other historical times, and can even contribute to modifying them - as has happened with Habermas' theory of public sphere and public opinion (Crossley \& Roberts, 2004; Boucheron \& Offenstadt, 2011). As Bourdieu (2000) argued, historicizing thought patterns makes it possible to distance oneself from discursive categories and constructions entrenched and naturalized in scholarship and disciplinary common sense. From this perspective, the study of political texts of the past can be useful for objectifying categories - such as reputation, social recognition, public opinion, public space, among others - that have become opaque due to excessive historical — and often implicit - use. In other words, it is possible to question Hobbes not so much by finding in his writings an idea of reputation management that attracts us by its familiarity, but by approaching forms of reputation management that are partial or obliterated by today's dominant and one-dimensional vision of the phenomenon.

Finally, one of the main concepts of contemporary philosophy is recognition. Public relations scholars have not paid enough attention to this from either a sociological or a historical perspective. Maybe it is time to fill this gap and, on the basis of historical thinkers as Hobbes, Rousseau, Fichte, Hegel, and modern and postmodern ones, as Kojève, Ricoeur and Honneth, offer a strong picture of how crucial is the role that recognition plays in, particularly, public relations considered as "a functional social system that provides organizations as well as individuals with legitimacy and trust" (Bentele \& Wehmeier, 2007, p. 299).

\section{References}

Bagby, L. M. (2009). Thomas Hobbes: Turning point for Honor. Lanham, MD: Lexington Books.

Bentele, G.; \& Wehmeier, S. (2007). Applying sociology to public relations: A commentary. Public Relations Review, 33(3), 294-300. 
Boucheron, P.; \& Offenstadt, N. (Eds.) (2011). L'espace public au Moyen Âge : Débats autour de Jürgen Habermas. Paris: Presses Universitaires de France.

Bourdieu, P. (1984). Distinction: A social critique of the judgement of taste. London: Routledge.

Bourdieu, P. (1986). The forms of capital. In J. G. Richardson (Ed.), Handbook of theory and research for the sociology of education (pp. 241-258). New York:

Greenwood.

Bourdieu, P. (1990). The logic of practice. Cambridge, UK: Polity.

Bourdieu, P. (1991). Language and symbolic power. Cambridge, UK: Polity.

Bourdieu, P. (2000). L'inconscient d'école. Actes de la recherche en sciences sociales, 135, 3-5.

Butler, J. (1990). Gender Trouble: Feminism and the Subversion of Identity. New York: Routledge.

Carnevali, B. (2012). Le apparenze sociali : Una filosofia del prestigio. Bologna: Il Mulino.

Carnevali, B. (2013). "Glory”: La lutte pour la réputation dans le modèle hobbesien. Communications, 93, 49-67.

Coombs, W. T., \& Holladay, S. J. (2012). Fringe public relations: How activism moves critical PR toward the mainstream. Public Relations Review, 38(5), 880-887.

Crossley, N.; \& Roberts, J. M. (Eds.) (2004). After Habermas: New Perspectives on the Public Sphere. Oxford: Blackwell.

Dodd, M. D.; Brummette, J; \& Hazleton, V. (2015).A social capital approach: An examination of Putnam's civic engagement and public relations roles. Public Relations Review, 41(4), 472-479.

Edwards, L. (2006). Rethinking power in public relations. Public Relations Review, $32(3), 229-231$.

Fitch, K.; \& L'Etang, J. (2017). Other voices? The state of public relations history and historiography: Questions, challenges and limitations of 'national' histories and historiographies. Public Relations Inquiry, 6(1), 115-136.

Frisby, D.; \& Featherstone, M. (Eds.) (1997). Simmel on Culture. London, UK: Sage.

García, C. (2010). Rethinking Walter Lippmann's legacy in the history of public relations. PRism 7(1). In: http://www.prismjournal.org 
García, C. (2015). Searching for Benedict de Spinoza in the history of communication: His influence on Walter Lippmann and Edward Bernays. Public Relations Review, 41(3), 319-325.

García, C. (2017). Ethics and strategy: A communication response to Machiavelli's The Prince in Baltasar Gracián's A pocket oracle. Public Relations Review.

Gordon, P. (2012). What is Intellectual History? A frankly partisan introduction to a frequently misunderstood field. Cambridge, MA: Harvard University. In: http://projects.iq.harvard.edu/files/history/files/what_is_intell_history_pgordon_mar201 2.pdf

Gracián, B. (1992 [1647]). The art of worldly wisdom. A pocket oracle. New York, NY: Doubleday.

Heath, R. L.; O'Hair, H. D. (2009). The significance of crisis and risk communication. In: R. L. Heath \& H. D. O'Hair (Eds.), Handbook of Risk and Crisis Communication (pp. 5-30). New York: Routledge.

Heath, R. L.; Xifra, J. (2016). What is critical about critical public relations theory? In: J. L'Etang, D. McKie, N. Snow \& J. Xifra (Eds). The Routledge Handbook of Critical Public Relations (pp. 200-210). New York: Routledge.

Hobbes, T (1969 [1640]). The Elements of Law: Natural and Politic. New York: Frank Cass (2nd ed.).

Hobbes, T (1996 [1651]). Leviathan or the Matter, Forme and Power of a Common Wealth Ecclesiasticall and Civil. Cambridge: Cambridge University Press,

Hobbes, T (1998 [1642]). On the Citizen. Cambridge: Cambridge University Press.

Honneth, A. (1995). The Fragmented World of the Social. Essays in Social and Political Philosophy. Albany, NY: State University of New York Press.

Honneth, A. (1996). The Struggle for Recognition: The Moral Grammar of Social Conflicts. New York: Polity Press.

Honneth, A. (2002). Grounding recognition: A rejoinder to critical questions. Inquiry, 45(4), 499-520.

Ihlen, Ø. (2005). The power of social capital: Adapting Bourdieu to the study of public relations. Public Relations Review, 31(4), 492-496.

Ihlen, Ø. (2007). Building on Bourdieu: A sociological grasp of public relations. Public Relations Review, 33(3), 269-274.

Ihlen, Ø.; Van Ruler, B.; Fredriksson, M. (Eds.) (2009). Public relations and social theroy: Key figures and concepts. London: Routledge. 
Landi, S. (2012). Au delà de l'espace public: Habermas, Locke et le consentement tacite. Revue d'Histoire Moderne et Contemporaine, 59(4), 7-32.

Lazzari, C. (1990). Les racines de la volonté de puissance. In: Y. C. Zarka \& J. Bernhardt (Eds.), Thomas Hobbes: Philosophie première, théorie de la science et politique (pp. 225-246). Paris: Presses Universitaires de France.

Lemetti, J. (2012). Historical Dictionary of Hobbes's Philosophy. Lanham, MD: The Scarecrow Press.

Marsh. C. (2013). Classical rhetoric and modern public relations: An Isocratean model. New York: Routledge.

Moloney, K. (2002) Rethinking Public Relations: The Spin and the Substance. London, UK: Routledge.

Moore, S. (2012). Ideals and realities: Renaissance state communication in Machiavelli's The Prince and More's Utopia. Public Relations Review, 38(3), 383-389.

Moore, S. (2014). Public relations and the history of ideas. London: Routledge.

Murphy, P. (1991). The limits of symmetry: A game theory approach to symmetric and asymmetric public relations. Public Relations Research Annual, 3, 115-131.

Orléan, A. (2011). L'empire de la valeur. Paris: Seuil.

Piirimäe, P. (2006). The explanation of conflict in Hobbes's Leviathan. Trames, $10(60 / 55), 1,3-21$.

Pizzorno, A. (1991). On the individualistic theory of social order. In: P. Bourdieu \& J. S. Coleman (Eds.), Social Theory for a Changing Society (pp. 209-244). Boulder, CO: Westview Press - Russell Sage Foundation.

Ricoeur, P. (2005). The course of recognition. Cambridge, MA: Harvard University Press

Roper, J. (2005). Symmetrical Communication: Excellent Public Relations or a Strategy for Hegemony? Journal of Public Relations Research, 17(1), 69-86.

Ryan, A. (2015). On Hobbes: Escaping the War of All Against All. New York: Liveright.

Slomp, G. (2014). Thomas Hobbes and the Political Philosophy of Glory. London: Palgrave MacMillan.

Sommerfeldt, E. J. (2013). The civility of social capital: Public relations in the public sphere, civil society, and democracy. Public Relations Review, 39(4), 280-289.

Sowerby, R. (1998). Thomas Hobbes's translation of Thucydides. Translation and Literature, 7(2), 147-169. 
Strauss, L. (1936). The Political Philosophy of Hobbes: Its Basis and Its Genesis.

Oxford, UK: The Clarendon Press.

Taylor, C. (1989). Sources of the Self: The Making of the Modern Identity. Cambridge, UK: Cambridge University Press.

Taylor, M. (2011). Social Capital as a Measure of Public Relations Impact. In: http://www.instituteforpr.org/social-capital-as-a-measure-of-public-relations-impact/

Thomas, K. (1965). The Social Origins of Hobbes's Political Thought. In K. C. Brown (ed.), Hobbes Studies (p. 185-236). Oxford, UK: Blackwell.

Williams, R. R. (1992). Recognition: Fichte and Hegel on the other. Albany, NY: State University of New York Press.

Xifra, J.; Ordeix, E. (2009). Managing reputational risk in an economic downturn: The case of Banco Santander. Public Relations Review, 35(4), 353-360.

Zarka, Y. C. (2016). Hobbes and modern political thought. Edinburgh, UK: Edinburgh University Press. 